\title{
Investment decisions as mediating of fundamental and technical factors on firm value
}

\author{
Fedy Romamti ${ }^{a^{*}}$, I Gusti Bagus Wiksuana ${ }^{a}$, Ida Bagus Anom Purbawangsa ${ }^{a}$ and Ida Bagus Panji Se- \\ dana $^{\mathrm{a}}$
}

${ }^{a}$ Economic and Business Faculty, Udayana University, Indonesia

\begin{tabular}{l}
\hline C H R O N I C L E \\
\hline Article history: \\
Received: February 27, 2021 \\
Received in revised format: \\
April 292021 \\
Accepted: May 6, 2021 \\
Available online: \\
May 6, 2021 \\
\hline Keywords: \\
Fundamental \\
Technical \\
Investment Decisions \\
Firm value
\end{tabular}

\section{A B S T R A C T}

This study aims to analyze the impact of fundamental and technical factors on firm value with investment decisions as a mediating variable. The samples were 12 companies at agricultural sector in the Indonesia Stock Exchange. The results show that leverage had a negative and significant effect on investment decisions and firm value. Profitability and trading volume had a positive and significant effect on investment decisions and firm value. Previous stock prices did not have any significant effect on investment decisions but a positive and significant effect on firm value. Investment decisions had a positive and significant effect on firm value. Leverage had a negative and significant effect on firm value through investment decisions. Profitability and stock trading volume had a positive and significant effect on firm value through investment decisions. Previous stock prices did not have any significant effect on firm value through investment decisions.

\section{Introduction}

The agricultural sector plays a very important role in the Indonesian economy. Based on data from the Indonesian Central Bureau of Statistics, the average value of Indonesia's agricultural exports for the 2012-2019 period reached 3.5 billion dollars. The concept and model of approach and agricultural management must consider important aspects. First, technological advances and growth in other sectors, especially in relation to the increasing world demand for food and various derivatives of agricultural products, both horticulture and food. Second, the Asean Economic Community (AEC), which is used as a space to penetrate the cross-Asian market, must maximize its opportunities, namely by making changes to changes in farming and product packaging so that they have added value / high competitiveness with other products in the market (https://setkab.go.id/posisi-pertanian-yang-tetap-strategis-masa-kini-dan-masa-depan/). The role of the agricultural sector in the demand for agricultural commodities on world markets is as shown in the graph in Table 1. The table explains that the role of the agricultural sector is evidenced by the export results of the agricultural sector. The development of exports of agricultural products from time to time shows a fluctuating trend both in terms of weight and value. The growth in the export value of agricultural products in 2014 and 2016 decreased by 6.26 percent and 9.98 percent, respectively. Meanwhile, the growth in the export value of agricultural products in 2015 and 2017 showed positive performance, namely increasing by 10.47 percent and 9.43 percent, respectively. Even so, the export value of agricultural products has again decreased by 6.54 percent in 2018. Finally, it has increased again in 2019 by 5.29 percent. The agricultural sector is one of the important sectors in economic development, both at the national and regional levels. The output of the agricultural sector contributes to various sectors of the economy, including foodstuff providers, feedstuff providers, raw materials for small, medium, and large industries, absorbing labor, and the main source of income for rural households. In addition, the agricultural sector supports the manufacturing sector, which is one of the main sectors supporting the country's economy.

* Corresponding author.

E-mail address: fedy_romamti@hotmail.com (F. Romamti)

(C) 2021 by the authors; licensee Growing Science, Canada doi: $10.5267 /$ j.ac.2021.5.004 
Table 1

Development of Agricultural Sector in 2012-2019

\begin{tabular}{|c|c|c|c|}
\hline Year & Net weight (thousand tons) & Value (USS million) & $\%$ Change in Value \\
\hline 2012 & $2,268.40$ & $3,597.70$ & 6.16 \\
\hline 2013 & $2,462.20$ & $3,598.50$ & 0.02 \\
\hline 2014 & $2,777.30$ & $3,373.30$ & -6.26 \\
\hline 2015 & $3,621.50$ & $3,726.50$ & 10.47 \\
\hline 2016 & $3,453.00$ & $3,354.80$ & -9.98 \\
\hline 2017 & $4,177.60$ & $3,671.00$ & 9.43 \\
\hline 2018 & $4,345.40$ & $3,431.00$ & -6.54 \\
\hline 2019 & $4,981.70$ & $3,612.40$ & 5.29 \\
\hline Average & $3,510.89$ & $3,545.65$ & 1.07 \\
\hline
\end{tabular}

In addition, the role of the agricultural sector is also very important, especially for absorption of the agricultural sector. In absolute terms, the creation of added value in the agricultural sector, which in this case is measured by the added value of GDP in the agricultural sector, has a positive effect on labor absorption in the agricultural sector as described in Table 2.

Table 2

Labor Absorption (Million people)

\begin{tabular}{|c|c|c|c|c|}
\hline Year & Agriculture & Non Agricultural & Total Workforce & Absorption Percentage \\
\hline 2012 & 36,048 & 74,379 & 110,808 & $32.53 \%$ \\
\hline 2013 & 35,763 & 76,963 & 113,011 & $31.65 \%$ \\
\hline 2014 & 35,769 & 82,401 & 118,170 & $30.27 \%$ \\
\hline 2015 & 35,474 & 88,839 & 124,313 & $28.54 \%$ \\
\hline 2016 & 35,649 & 90,277 & 125,926 & $28.31 \%$ \\
\hline 2017 & 35,956 & 91,715 & 128,671 & $28.72 \%$ \\
\hline 2018 & 35,871 & 94,153 & 130,024 & $27.59 \%$ \\
\hline 2019 & 35,572 & 94,157 & 130,729 & $27.98 \%$ \\
\hline Average & 35,763 & 86,611 & 122,707 & $29.45 \%$ \\
\hline
\end{tabular}

Source: Ministry of Agriculture (2019)

During the 2012-2019 period, the agricultural sector was still a sector with a large share of employment, although there was a downward trend. The absorption of labor in the agricultural sector in 2012 was around 36,048 million workers or around $32.53 \%$ of the total employment. Then it decreased in 2019, the absorption of labor has decreased to 35,572 million workers or $27.98 \%$. Apart from that, the role of the agricultural sector is also proven by the agricultural sector which is able to survive during the economic crisis. As evidence, in 2008 when the world faced a global financial crisis, the agricultural sector was able to survive compared to other sectors. In 2007, namely the beginning of the financial crisis in the USA, Indonesia's economic growth was at a relatively good rate of 6,3\%. (BI Annual Report, 2007) When the crisis spreads throughout the world, Indonesia as an open country cannot avoid the impact of the global economic crisis, although in terms of growth it can still reach $6.1 \%$, lower than before. This indeed shows that at an early stage, the impact of the global economy will not have much effect on economic growth. However, the impact of the global economic impact was greater in 2008 , namely $4.5 \%$ and in 2009 Indonesia's economic growth was still 5.5\%. In the following years (2011-2014), it is predicted that growth will be achieved between $6.5 \%$ to $7.5 \%$ per year (BI Annual Report, 2007). Based on the role of the agricultural sector described earlier, the agricultural sector has promising business development prospects. But in reality companies in the agricultural sector, especially those that carry out activities on the Indonesia Stock Exchange, have not experienced optimal development. This is evidenced by the development of the agricultural sector index price described in Fig. 1.

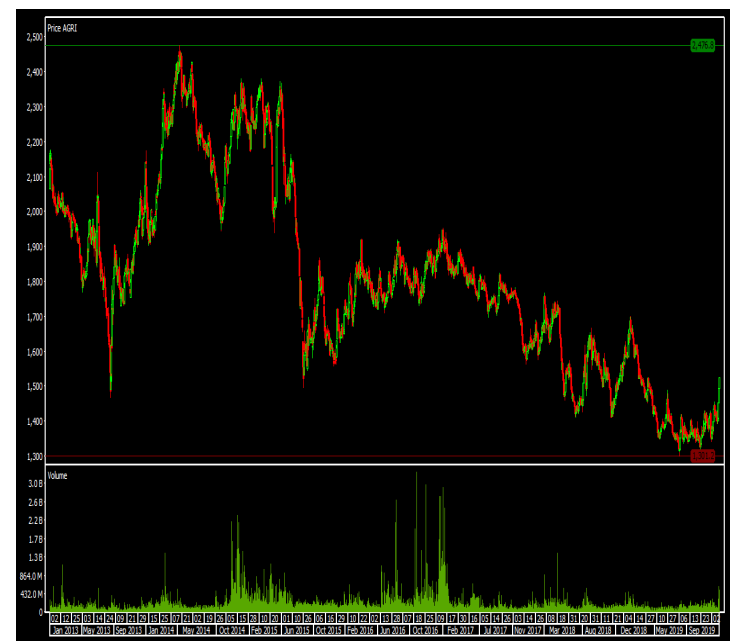

Fig. 1. Development of Agricultural Sector Index Prices

Source: PT. Indopremier Sekuritas (2019) 
Fig. 1 explains that the agricultural sector index price has decreased over time. Data shows that in semester 1 of 2014 it decreased and in semester 2 of 2014 experienced a stable condition (stagnant) but since 2015-2019 it decreased. This is because, in general, companies in the agricultural sector are in the plantation sector, which sell a lot of palm oil production, causing a decline in the stock price index. The decline in the agricultural sector index price is related to developments in the volume of stock trading which also experienced fluctuating developments but tended to decline as shown in Figure 1. The development of stock trading from the agricultural sector. From 2016 to June 2020 there were fluctuating developments but tended to decline. Based on the role of the agricultural sector described earlier, the agricultural sector actually has promising business development prospects. There are several factors that affect the fluctuation of company value, including fundamental factors and technical factors. Fundamental factors based on company financial data, and technical factors based on patterns of stock movements from time to time. This study used two fundamental factors of financial ratios, namely leverage and profitability. Previous studies examining the impact of leverage on firm value have shown mixed results. Chen and Chen (2011), Cheng and Tzeng (2011), Zuhroh (2019), Jeleel and Olayiwola (2017), Farooq dan Masood (2016), Ramadan (2015), Zaigham et al. (2019), Balakrishnan and Ramachandran (2016), found that leverage has a positive and significant effect on firm value. Paminto et al. (2016) and Handoko (2017) found that Leverage has a negative and significant effect on firm value. Companies that have a high level of profitability will attract investors to their shares. Marsha and Murtaqi (2017), Sabrin et al (2016), Tui (2017) and Rely and Arsjah (2017) found that profitability has a positive and significant effect on firm value.

This study used proxy for the previous stock price and trading volume in the assessment of technical factors. This proxy selection is based on the results of empirical testing in previous research and technical assessments based on stock prices and trading volume as benchmarks for the company's success in increasing firm value. Zaigham (2019), Chandrapala (2011), Yahyazadehfar (2010), Lee et al. (2018), Chipunza (2017) found that technical factors have a significant effect on firm value. Meanwhile, Tapa and Hussin (2016), Drakopoulou (2015) found that technical factors had no significant effect on firm value. Firm value is also influenced by investment. Firm value is the owner's perception of the company's investment success. Reuer and Tong (2017), Lee et al. (2018), Da Silva et al. (2013) found that investment growth increases firm value.

This paper contributes to the existing literature in the following ways: Firstly, the finding of the current paper reconciles the mixed results regarding the impact of leverage on firm value in emerging markets by profitability increases value of firm. Secondly, the paper offers insights into how market conditions affect investment and firm value in the Indonesia stock market where the research in relation to this issue has rarely been executed.

\section{Literature review}

The optimal capital structure is expressed as a combination of debt, preference, and equity. Companies that wish to maximize investment will estimate their optimal capital structure. Increased use of debt can suppress excessive free cash flows where there are company cash flows that are not invested profitably. Empirical evidence is shown by Mondosha and Majoni (2016) and Sajid et al. (2016) explained that the leverage ratio has a negative and significant effect on investment decisions.

$\mathbf{H}_{1}$ : Leverage has a negative and significant effect on investment decisions.

Profitability is an indicator of the company's management performance in managing the company's assets. Profits can also be a source of investment funding. Growing companies use profits to reinvest. Kuroda et al. (2015), Muzaffar (2015), Zaigham et al. (2019), Da Silva et al. (2013), Muhammad and Ali (2018), Franklin and Muthusamy (2015), Ikeobi and Bitrus (2016), Muzaffar (2015), Baresa and Ivanovic (2016), Maulina et al. (2018) found that profitability has a positive and significant effect on investment decisions

$\mathbf{H}_{2}$ : Profitability has a positive and significant effect on investment decisions.

The stock price that is formed in the market already reflects all available information. High share prices reflect investors' expectations of the company's growth. Suresh (2013), Seetharaman et al. (2017), Risman et al. (2017), Ruhani and Quddus (2018), Hoffmann and Shefrin (2014), Masry (2017), Pushpe et al. 2017), Makarim and Noveria (2014), Wang et al. (2014), Zaigham (2019) and Boumosleh (2012) found that stock prices have a positive and significant effect on investment decisions.

H3: Previous stock prices have a positive and significant effect on investment decisions.

The total volume of stock activity is determined by supply and demand. As with stock prices, the trading volume y reflects investors' expectations of the company's investment prospects. Ruhani and Quddus (2018), Masry (2017) and Zaigham et al. (2019) found that trading volume has a positive and significant effect on investment decisions.

$\mathbf{H}_{4}$ : Stock trading volume has a positive and significant effect on investment decisions.

Debt can be used as leverage to increase the company's operating capital to get a profit which will increase the company's value. Debt can reduce tax expenditures, thus increasing company value. However, debt that is too high also makes the company's financial condition unhealthy so that it can reduce the company's value. Empirical evidence with the results of research by Paminto et al. (2016) and Handoko (2017) state that leverage has a negative and significant effect on firm value.

Hs: Leverage has a negative and significant effect on firm value.

Fundamental factors as measured by financial performance can increase company value. Profitability has a positive and significant effect on firm value. High profit gives an indication of the company's good prospects so that it can trigger capital 
owners to participate in increasing share demand. The increasing demand for shares causes the company value to increase. Zuhroh (2019), Jeleel and Olayiwola (2017), Marsha and Murtaqi (2017), Sabrin et al (2016), Handoko (2017), Rely and Arsjah (2017), Tui et al. (2017) Cheung et al. (2015), Drakopoulou (2015), Husna and Satria (2019) and Da Silva et al. (2013) found that profitability has a positive and significant effect on firm value.

H6: Profitability has a positive and significant effect on firm value.

Boumosleh (2012), Sidhu (2016), Zulkarnaen et al. (2016), Zaigham et al. (2019), Yahyazadehfar et al. (2010), Lee et al. (2018), Chipunza et al. (2017) and Drakopoulou (2015) explain that stock prices can have a positive and significant effect on firm value. Firm value is the owner's perception of the company's success rate which is often associated with the stock price. The high share price makes the company value also high. A high company value will make the market believe not only in the company's current performance but also in the company's future prospects.

H7: Previous stock price has a positive and significant effect on firm value.

The trading volume of share prices is determined by supply and demand. The higher the trading volume shows that the company's shares are in demand by investors, thereby increasing the company's value. Zulkarnaen et al. 2016), Zaigham et al. 2019), Chandrapala (2011) and Chipunza et al. (2017) found that trading volume has a positive and significant effect on firm value.

Hs: $_{8}$ Stock trading volume has a positive and significant effect on firm value.

The decision to allocate capital into investment proposals whose benefits will be realized in the future must be carefully considered. Due to uncertainty in the future, the benefits are uncertain, so that the investment proposal carries risks. Ahmad and Siahaan (2016), Reuer and Tong (2017), Handriani and Robiyanto (2018), Umrie and Yuliani. (2014), Lee et al. (2018), Da Silva et al. (2013) and Yulia (2017 found that investment decisions have a positive and significant effect on firm value.

H9: investment decisions have a positive and significant effect on firm value.

\section{Methods}

Data and Sample Selection The data is obtained from the company's annual reports of 12 companies in the agricultural sector which are continuously listed on the Indonesia Stock Exchange in 2012-2018.

Model Specification The hypothesized relationship between the research variables is formulated in the regression model in Eq. (1) and Eq. (2).

$$
\begin{aligned}
& I N V=\alpha_{1}+\beta_{11} \times L E V+\beta_{12} \times P R O F I T+\beta_{13} \times P R I C E+\beta_{14} \times V O L+e_{1} \\
& V A L U E=\alpha_{2}+\beta_{21} \times L E V+\beta_{22} \times P R O F I T+\beta_{23} \times P R I C E+\beta_{24} \times V O L+\beta_{25} \times I N V+e_{2}
\end{aligned}
$$

where INV is a company's investment, calculated from the company's assets this year minus the previous year's assets divided by the previous year's assets. $L E V$ is the company's leverage, calculated from total debt divided by equity. Profit is the company's profitability, calculated from net income divided by total assets. PRICE is the previous share price. $V O L$ is the trading volume of the company's shares. VALUE is the company value, calculated from the company's share price divided by earnings per share.

\section{Results}

\subsection{Descriptive Statistics}

The average leverage of the company is $6.08 \%$. Leverage value is in the range of $-17.31 \%$ to $37 \%$. This means that the sample companies have low leverage. Profitability was in the range $-45 \%$ to $50 \%$, with a mean of $11 \%$.

\section{Table 1}

\begin{tabular}{|c|c|c|c|c|}
\hline Variable & Minimum & Maximum & Mean & Std. Deviation \\
\hline LEV & $-17,31$ & 37,00 & 6,08 & 44,08 \\
\hline PROFIT & $-0,45$ & 0,50 & 0,11 & 0,52 \\
\hline PRICE & 21,00 & $59.125,00$ & $2.714,00$ & $7.934,00$ \\
\hline VOL & 1,00 & $3.122 .538,00$ & $164.048,89$ & $583.285,94$ \\
\hline INV & $-1,00$ & 11,00 & 0,39 & 1,51 \\
\hline VALUE & $-70,00$ & 115,89 & 53,68 & 84,03 \\
\hline
\end{tabular}

Descriptive Statistics Variable

\subsection{Results}

The path analysis results of equation 1 are shown in Table 2 . The four independent variables in model 1 have one regression coefficient that is not significant, namely the PRICE variable, so the third hypothesis which states that the previous stock price 
has a positive effect on company investment is rejected. The regression coefficients of other variables in model 1 are statistically significant, and with a coefficient sign that matches the research hypothesis, so that the first, second and fourth research hypotheses are accepted.

Table 2

Regression results for Eq. (1).

\begin{tabular}{lcccc}
\hline Variable & Coefficient & t-statistic & p-value & Hypothesis Test \\
\hline CONSTANT & 1,020 & 1,377 & 0,173 & H1 accepted \\
LEV & $-0,317$ & $-3,371$ & 0,001 & H2 accepted \\
PROFIT & 0,541 & 5,874 & 0,000 & H3 rejected \\
PRICE & 0,046 & 0,466 & 0,643 & 0,035 \\
VOL & 0,071 & 3,786 & H4 accepted & \\
\hline
\end{tabular}

The regression results of Eq. (2) are shown in Table 3. All independent variables in model 2 are statistically significant, with a coefficient sign in accordance with the research hypothesis. Thus, the fifth to ninth hypotheses are accepted.

Table 3

Regression results for Eq. (2)

\begin{tabular}{lcccc}
\hline Variable & Coefficient & t-statistic & P-value & Hypothesis Test \\
\hline CONSTANT & 0,976 & 1,298 & 0,199 & H \\
LEV & $-0,313$ & $-3,298$ & 0,002 & 0,000 \\
PROFIT & 0,533 & 5,646 & 0,020 & H6 accepted \\
PRICE & 0,048 & 2,484 & 0,025 & H7 accepted \\
VOL & 0,073 & 2,803 & 0,024 & H8 accepted \\
INV & 0,040 & 2,450 & H9 accepted & \\
\hline
\end{tabular}

Leverage has a negative and significant effect on investment decisions. This means that each increase in the level of leverage decreases investment decisions. A company that has high leverage means that the company uses high debt, thereby reducing investment decisions. This is due to the large amount of debt the company has, so it will reduce cash flow because of the interest costs paid. Profitability has a positive and significant effect on investment decisions. Profitability shows the company's ability to manage assets so as to generate high profits. Previous share prices have no significant effect on investment decisions. This indicates that any decrease or increase from the previous share price growth rate will neither decrease nor increase the growth rate of investment decisions. Stock trading volume has a positive and significant effect on investment decisions. A small trading volume indicates low share buying and selling transactions, thus preventing the company from adding sources of funds to invest. Leverage has a negative and significant effect on firm value. In accordance with the pecking order theory (Myers, 1977), companies with low profitability will have relatively few internal funds so that they require more external funding, which mainly comes from debt. Profitability has a positive and significant effect on firm value. The higher the profitability figure listed in the financial statements, the better the company's financial performance, it will reflect the company's greater wealth and the company's prospects in the future are considered more promising. Previous stock prices have a positive and significant effect on firm value. Previous stock prices provide information on whether a stock price data has a tendency to stay on a trend or not. Trading volume has a positive and significant effect on firm value because volume reflects the information received by market players, this information causes a positive relationship between volume and firm value. Investment decisions have a positive and significant effect on firm value. High investment is a signal of the company's future revenue growth.

\section{Conclusion}

This study proves and strengthens the results of previous research that investment decisions and firm value are still dominated by fundamental factors such as leverage and profitability and technicality so that in an effort to improve investment decisions and firm value factors such as profitability, leverage, trading volume are still considered in increasing firm value. In general, the findings of the influence of fundamental factors on investment and firm value indicate that high debt limits investment and reduces firm value. Companies use profit as a source of investment funding and ultimately increase company value. The test results show that the company increases its investment following the conditions of the capital market, when the transaction volume is high.

\section{Limitation}

There are several limitations to the study, including: a. The research population is only in the agricultural industry group so that the research observations are still not representative of companies listed on the IDX. $b$. The time span of the research is only six years, from 2013 to 2018, so the results are less accurate and generalized, so there is no comparison with the longer research period. c. The variables in this study only use six variables, namely the variable profitability, leverage, previous stock prices, share trading volume and investment decisions so that the variables that affect investment decisions and firm value are still limited.

\section{References}

Ahmad, G. N. (2011). Analysis Of Financing Decision, Investment Decision, Dividend Policy And Value Of The Firm That Listed On Kompas 100 Index Period 2007-2009. Jurnal Riset Akuntansi dan Komputerisasi Akuntansi, 6, 1-18. 
Balakrishnan, C., \& Ramachandran, M. K. (2016). On the Determinants of Firm Value of Indian Companies. Available at SSRN 2874086.

Baresa, S., Bogdan, S., \& Ivanovic, Z. (2016). Capital investments and financial profitability. UTMS Journal of Economics, 7(1), 49-59.

Boumosleh, A. (2012). Firm Investment Decisions, Dividend Policy, And Director Stock Options. Journal of Applied Business Research (JABR), 28(4), 753-768.

Badan Pusat Statistik. (2019) Analisis Komoditas Ekspor, 2012-2019, Sektor Pertanian, Industri Dan Pertambangan. Jakarta: BPS

Chandrapala, P. (2011). The relationship between trading volume and stock returns. Journal of Competitiveness, 3(2). $41-49$

Chen, L. J., \& Chen, S. Y. (2011). The influence of profitability on firm value with capital structure as the mediator and firm size and industry as moderators. Investment Management and Financial Innovations, 8(3), 121-129.

Cheng, M. C., \& Tzeng, Z. C. (2011). The effect of leverage on firm value and how the firm financial quality influence on this effect. World Journal of Management, 3(2), 30-53.

Cheung, W. M., Chung, R., \& Fung, S. (2015). The effects of stock liquidity on firm value and corporate governance: Endogeneity and the REIT experiment. Journal of Corporate Finance, 35, 211-231.

Chipunza, K. J., \& McCullough, K. (2018). The impact of internationalisation on stock liquidity and volatility: Evidence from the Johannesburg Stock Exchange. Journal of Economic and Financial Sciences, 11(1), 11.

Da Silva, A. F., Vieira, A. M. C., Navarro, A. C., \& Parisi, C. (2013). Decisions on investment and profitability: An empirical study using generalized linear mixed models in non-financial Brazilian companies. In European Financial Management Association (EFMA) Annual Conference, UK.

Drakopoulou, V. (2016). A review of fundamental and technical stock analysis techniques. Journal of Stock \& Forex Trading, 5.

Farooq, M. A., \& Masood, A. (2016). Impact of financial leverage on value of firms: Evidence from cement sector of Pakistan. Research Journal of Finance and Accounting, 7(9), 73-77.

Franklin John, S., \& Muthusamy, K. (2011). Impact of leverage on firms investment decision. Journal of Scientific dan Engineering Research, 2(4), 145-156

Handoko, P. (2017). The Influence of Firm's Size, Growth, and Profitability on Firm Value with Capital Structure as the Mediator: A Study on the Agricultural Firms Listed in the Indonesian Stock Exchange. International Journal of Economics and Finance, 9(8), 103-110.

Handriani, E., \& Robiyanto, R. (2018). Corporate Finance and Firm Value in the Indonesian Manufacturing Companies. International Research Journal Of Business Studies, 11(2), 113-127.

Husna, A., \& Satria, I. (2019). Effects of return on asset, debt to asset ratio, current ratio, firm size, and dividend payout ratio on firm value. International Journal of Economics and Financial Issues, 9(5), 50.

Ikeobi, N. R., \& Jat, R. B. (2016). Fundamental factors influencing individual investors to invest in shares of manufacturing companies in the Nigerian capital market. Research Journal of Finance and Accounting, 7(8), 93-98.

Jeleel, A., \& Olayiwola, B. (2017). Effect of Leverage on Firm Performance in Nigeria: A Case of Listed Chemicals and Paints Firms in Nigeria. Global Journal of Management And Business Research, 17(2).

Kementerian Pertanian Indonesia. (2019). Statistik Ketenagakerjaan Sektor Pertanian. Jakarta: Departemen Pertanian

Kuroda, A. M., \& de Albuquerque, A. A. (2015). Theoretical Essay About The Relation Between Financial Leverage And Investment In Brazilian Companies. Revista de Gestão, Finanças e Contabilidade, 5(4), 6.

Lee, Y. J., Wang, G. L., Kao, K. S., Chen, C. Y., \& Zhu, F. P. (2010). The investment behavior, decision factors and their effects toward investment performance in the Taiwan stock market. Journal of Global Business Management, 6(2), 1.

Makarim, R. F., \& Noveria, A. (2014). Investment Decision Based On Financial Performance Analysis And Market Approach Valuation Of Indonesian Construction Sector. Journal of Business And Management, 3(7), 799-812.

Marsha, N., \& Murtaqi, I. (2017). The effect of financial ratios on firm value in the food and beverage sector of the IDX. Journal of Business and Management, 6(2), 214-226.

Masry, M. (2017). The impact of technical analysis on stock returns in an emerging capital markets (ECM's) country: Theoretical and Empirical Study. International Journal of Economics and Finance, 9(3), 91-107.

Maulina, P. A., \& Dewi, R. R. (2018, August). Analysis of Effect of Dividend Policy, Policies Debt, Profitability and Investment Decision in the Value of The Company. In PROCEEDING ICTESS (Internasional Conference on Technology, Education and Social Sciences).

Mondosha, M., \& Majoni, A. (2018). The impact of leverage on investment decisions for South African firms with different growth opportunities. Journal of Economic and Financial Sciences, 11(1), 7.

Muhammad, S., \& Ali, G. (2018). The relationship between fundamental analysis and stock returns based on the panel data analysis; evidence from karachi stock exchange (kse). Research Journal of Finance and Accounting, 9(3), 84-96.

Muzaffar, B. (2015). The Impact of Leverage on the Investment of the Firms. Asian Journal of Humanities and Social Studies, 3(4).

Myers, S. C. (1977). Determinants of corporate borrowing. Journal of financial economics, 5(2), 147-175.

Pushpe, B., Sumithra, C., \& Madhuri, H. (2007). Investment Decision Making Using Technical Analysis: A Study on Select Stocks in Indian Stock Market. IOSR Journal of Business and Management, 24-33.

Rely, G., \& Arsjah, R. J. (2017). An Effecting of Foregin ownership structure in firm value towards offshore debt financing in Manufacturing Firms. Target, 1(2017), Q2. 
Reuer, J. J., \& Tong, T. W. (2007). Corporate investments and growth options. Managerial and Decision Economics, 28(8), 863-877.

Risman, A., Salim, U., Sumiati, S., \& Indrawati, N. K. (2017). Commodity Prices, Exchange Rates and Investment on Firm's Value Mediated by Business Risk: A Case from Indonesian Stock Exchange. European Research Studies Journal, 20(3A), 511-524.

Sabrin, A., Sarita, B., Takdir, D., \& Sujono, C. (2016). The effect of profitability on firm value in manufacturing company at Indonesia Stock Exchange. The International Journal of Engineering and Science, 5(10), 81-89.

Seetharaman, A., Niranjan, I., Patwa, N., \& Kejriwal, A. (2017). A study of the factors affecting the choice of investment portfolio by individual investors in Singapore. Accounting and Finance Research, 6(3), 153.

Sidhu, M. K. (2012). Stock Market Liquidity and Firm Value-Indian Evidences. IOSR Journal of Business and Management, 54-59.

Suresh, A. S. (2013). A study on fundamental and technical analysis. International Journal of Marketing, Financial Services \& Management Research, 2(5), 44-59.

Tapa, A., \& Hussin, M. (2016). The relationship between stock return and trading volume in Malaysian ACE market. International Journal of Economics and Financial Issues, 6(7S).

Tui, S., Mahfud, N., Mukhlis, S., \& Andi, N. (2017). Determinants of profitability and firm value: Evidence from Indonesian banks. IRA-International Journal of Management and Social Sciences, 7(1).

Umrie, H. R. H., \& Yuliani, Y. (2014). Ownership structure, innovation to firm value with the financing decision as mediation. Journal of Economics, Business, \& Accountancy Ventura, 17(2), 245-258.

Wang, Y. C., Yu, J., \& Wen, S. Y. (2014). Does fundamental and technical analysis reduce investment risk for growth stock? An analysis of Taiwan stock market. International Business Research, 7(11), 24.

Yahyazadehfar, M., Aghajani, H., \& Shahbandeh, M. (2010). A Comparison between Growth and Value Stocks of Listed Companies in Tehran Stock Exchange. Iranian Economic Review, 15(26), 67-81.

Zaigham, G. H. K., Wang, X., \& Ali, H. S. (2019). Causal relation between stock market performance and firm investment in China: Mediating role of information asymmetry. SAGE Open, 9(4), 2158244019885146.

Zuhroh, I. (2019). The Effects of Liquidity, Firm Size, and Profitability on the Firm Value with Mediating Leverage. KnE Social Sciences, 203-230. 
(C) 2021 by the authors; licensee Growing Science, Canada. This is an open access article distributed under the terms and conditions of the Creative Commons Attribution (CC-BY) license (http://creativecommons.org/licenses/by/4.0/). 